\title{
SITUATIONAL AWARENESS - KEY SAFETY FACTOR FOR THE OFFICER OF THE WATCH
}

\author{
Hrvoje Jaram, Pero Vidan, \\ Srđan Vukša, Ivan Pavić \\ University of Split (Bulgaria)
}

\begin{abstract}
One of the main causes of many maritime accidents are errors caused by the human element. Analysis of many maritime accidents at sea shows that situational awareness is one of the most important safety factors. The purpose and objective of this paper is to define the concept, importance and application of situational awareness throughout history until today. It also aims to highlight the high level of situational awareness as an important safety factor possessed by the Officer of the Watch and the overall importance of the same in the maritime domain. It is important to define the role of International Maritime Organization and the World Health Organization in relation to seafarer regulations and situational awareness. To identify the prevalence of low situational awareness as a root cause of accidents through the analysis of statistical data. To demonstrate the consequences of low situational awareness among ship's crew through examples of tragic maritime accidents, along with identifying human and organizational factors that significantly reduce situational awareness. By defining the role and application of maritime training and modern technological solutions in the efforts to prevent maritime accidents and improve the situational awareness of ship officers. The questionnaire was conducted with the aim of collecting data on the importance of situational awareness from the experienced mariners as a target group. The questionnaire also aimed to obtain more detailed information about the effectiveness offered by modern technological solutions to improve situational awareness. Based on the collected information, arguments and assertions about situational awareness as an important safety factor for the Officer of the Watch, safety recommendations are presented.
\end{abstract}

Keywords: situational awareness; human factor; questionnaire; maritime officers; maritime accidents

\section{Introduction}

In maritime transport, one of the main and major causes of many accidents is the human factor. Situational awareness is one element of a much broader concept known as human factors. Situational awareness is defined as the awareness of one's 
surroundings and can be divided into three levels, which are described in the further chapters (Towns 2007). Situational awareness can also be defined as understanding the current situation. It is the ability to look, evaluate relevance, synthesize large amounts of information, and make a correct decision and act in a timely manner ${ }^{1}$.

Throughout history, there have been many attempts to define and explain the concept of situational awareness. However, the most commonly cited and widely accepted definition from aviation states that situational awareness is: "perception of environmental elements in space and time, understanding of their meaning, and their projections into the near future" (Endsley 1995).

The concept of situational awareness was first proposed during World War I by O. Boelcke, a German fighter pilot. His concept was about getting an awareness of the enemy before the enemy gets an awareness of you. In the 1990s, situational awareness was introduced as a human factor and gained much interest in the aviation industry (Pico et all. 2015). From the aviation industry, this concept was transferred to the maritime industry because of the similarity in decision making and the amount of information that needs to be processed.

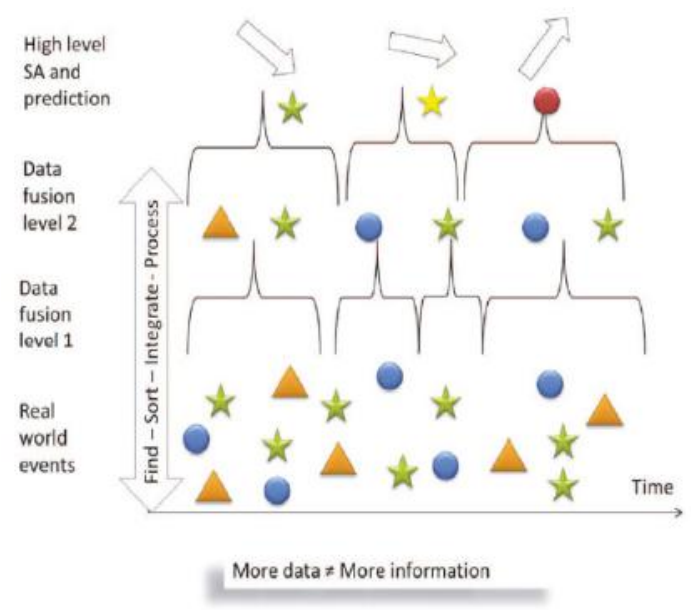

Figure 1. The Information gap (Koskinen-Kannisto 2013)

Figure 1. visualizes the problematic flood of data that needs to be processed before the required information is received. It is evident that situational awareness is an important factor in processing and understanding large amounts of data and is essential for the officer of the watch (Koskinen-Kannisto 2013).

Situational awareness can be most simply described as the ability to be alert and aware of all the circumstances a person finds themselves in on a daily basis. Most jobs take place in monotonous and repetitive environments, so the level of 
situational awareness of an average individual will be low. There is an established belief that a person has a heightened level of observation as an automatic response when they are in dangerous and emergency situations. As stated, the average person does not pay enough attention to situational awareness. Although the term originated in aviation, its application in the maritime industry as an important safety factor for safe navigation and life at sea is widespread, accepted, analyzed and increasing.

According to the American Bureau of Shipping, $80-85 \%$ of maritime accidents are predominantly caused by poor situational awareness. $50 \%$ of accidents are initiated by and $30 \%$ are associated with human factor. Those associated with the human factor imply that something other than human error set the course for dangerous accidents and that human performance deficiencies led to the inability to prevent or minimize the effects of the accident and thus avoid the disaster (Endsley 1995).

In his research, author M. L. Barnett summarized sources of human error and stated "Knowledge-based errors can occur when we have to think our way through a novel situation for which we have no procedure or "rule". Lack or loss of situational awareness is an example of a knowledge-based error" (Barnett 2005). Although procedures are created and implemented for most situations on board, there is always room for improvement. It is also important to consider that being overloaded with paperwork and completing numerous procedures can reduce or distract an officer's situational awareness.

The situation is the same with modern technologies. They are of great importance and aid the officer of the watch to gather and process large amounts of information. However, an increasing number of various modern automation devices are not trouble-free for the officer of the watch. The tireless efforts of ship owners and the shipping industry to introduce modern electronic aids to improve the safety of navigation and reduce the errors of the human factor. On the contrary, it is now considered that, among other things, this has greatly disturbed the situational awareness and due diligence of the officer on board (Pazouki et all. 2018). Another important issue for situational awareness is the relationship between human and modern technology (ship ergonomics), which is still a cause of many maritime accidents (Bielić et all. 2017)

Nowadays, the concept of situational awareness is widely recognized as a key factor that forms the basis for making correct and timely decisions, not only in aviation but also in various business and social environments such as maritime, military, police, nuclear facilities, and sports (Endsley 2015).

For the purpose of this thesis, a similar questionnaire was used as in the article "Practice of and attitudes toward familiarization on board: Survey of Croatian and Montenegrin marine officers", but with the theme of situational awareness (Vidan et al. 2018). The results are presented in chapter 6 . 


\section{Role of international organizations and regulatios for combating bad situational awareness in maritime industry}

Unfortunately, numerous disasters and accidents have had to occur throughout maritime history to encourage and stimulate International Organizations additional efforts to improve safety at sea. Almost every convention, regulation or standard has been associated with a particular catastrophic accident (Schröder-Hinrichs et al. 2013).

The main organization that plays a major role in maritime safety is the IMO (International Maritime Organization). IMO "is the United Nations specialized agency with responsibility for the safety and security of shipping and the prevention of marine and air pollution from ships". IMO attempts to cover all aspects of maritime safety and security through various conventions ${ }^{2)}$.

The first such convention was SOLAS (Safety of Life at Sea), which was adopted in 1914. It must be mentioned that the Titanic disaster was the trigger for the development of the said convention. The main objective of the SOLAS convention is to set minimum standards for the design and equipment of ships. In the context of situational awareness, the aim of the navigation equipment and its design located on the ship bridge and engine is to provide uninterrupted and unobstructed access to key data, in such a way that it should be clearly and accurately presented to watchkeeping officers through interfaces (Sandhåland et al. 2015).

The next convention to improve the human factor is the STCW Convention (The International Convention on Standards of Training, Certification and Watchkeeping for Seafarers). It was adopted in 1978. and entered into force in 1984. Since its entry into force, the Convention has been further improved by a number of amendments to enhance the safety of seafarers and safe navigation in general. The Convention sets minimum standards for the training and qualifications of crew members depending on their position on board ships ${ }^{3)}$.

In addition, the 2010 Manila Amendment to the STCW Convention, better known as "The Manila Amendments", emphasized the development and promotion of crew members' non-technical skills. Skills such as situational awareness, decision making, leadership and working as part of a team. The importance of these skills was recognized and emphasis was placed on them from the beginning of the training of future seafarers (Türkistanli 2019).

The World Health Organization published the "Pre-sea and periodic medical and fitness examinations" in 1997 with International Labour Organization, which were adopted and improved by the IMO through Maritime Labour Convention and the STCW Convention. Since examination standards varied in most countries, the plan was to create a harmonized international standard for health examinations. Doctors conducting the examinations need to understand the special occupational requirements of seafaring, as their judgment can be critical in preventing mishaps or serious accidents caused by health deficiencies and abnormalities in potential seafarers. The medical examination includes vision, hearing, fitness and psychological tests ${ }^{4}$. 
In terms of situational awareness, health deficiencies of individuals, such as poor hearing or vision, can hinder or limit proper perception and thus understanding of needed data and put everyone on board a ship at great risk.

Before boarding a ship, every seafarer must undergo an international medical examination, as this is an important basis for safe navigation and protection of their own health and that of other crew members ${ }^{4}$. Table 1 presents legislative initiatives after disastrous maritime accidents

Table 1. Examples of ${ }^{4)}$

\begin{tabular}{|c|c|c|c|c|}
\hline Year & Name of the ship & Organization & Measures/Instruments & $\begin{array}{l}\text { Effective } \\
\text { from }\end{array}$ \\
\hline 1912 & Titanic & IMO & $\begin{array}{l}\text { SOLAS 1914, 1929, 1948, } \\
1960,1974\end{array}$ & 1980 \\
\hline \multirow{3}{*}{1967} & \multirow{3}{*}{ Torrey Canyon } & \multirow{3}{*}{ IMO } & $\begin{array}{l}\text { Intervention } 1969 \text { Conven- } \\
\text { tion, }\end{array}$ & 1975 \\
\hline & & & MARPOL, 1973 & 1983 \\
\hline & & & CLC, 1969 & 1975 \\
\hline 1976 & Argo Merchant & IMO & $\begin{array}{l}\text { MARPOL, } 1973 \text { - Protocol } \\
\text { of } 1978\end{array}$ & 1983 \\
\hline \multirow[b]{3}{*}{1987} & \multirow{3}{*}{$\begin{array}{l}\text { Herald of Free } \\
\text { Enterprise }\end{array}$} & \multirow[b]{3}{*}{ IMO } & ISM CODE, 1994 & 1998 \\
\hline & & & SOLAS 1988 amendments & 1989 \\
\hline & & & $\begin{array}{l}\text { SOLAS } 1988 \text { (amendments } \\
\text { - SOLAS } 90 \text { (Stability } \\
\text { standards) }\end{array}$ & 1990 \\
\hline 1990 & Scandinavian Star & IMO & $\begin{array}{l}\text { SOLAS } 1989 \text { amendments } \\
\text { (Fire protection) }\end{array}$ & 1992 \\
\hline \multirow[b]{2}{*}{1989} & \multirow[b]{2}{*}{ Exxon Valdez } & \multirow[b]{2}{*}{ IMO } & OPRC, 1990 & 1995 \\
\hline & & & $\begin{array}{l}\text { MARPOL } 1992 \text { amend- } \\
\text { ments (Double hull) }\end{array}$ & 1995 \\
\hline \multirow{4}{*}{1994} & \multirow{4}{*}{ Estonia } & \multirow[b]{2}{*}{ IMO } & $\begin{array}{l}\text { SOLAS } 1995 \text { amendments } \\
\text { (Stability, Safety equipment) }\end{array}$ & 1997 \\
\hline & & & $\begin{array}{l}\text { SAR Convention, } 1998 \\
\text { amendments (improving } \\
\text { cooperation) }\end{array}$ & 2000 \\
\hline & & \multirow{2}{*}{ EU } & $\begin{array}{l}\text { Regulation of safety man- } \\
\text { agement on-board ro-ro } \\
\text { vessels }\end{array}$ & 1995 \\
\hline & & & $\begin{array}{l}\text { Guidelines for inspection } \\
\text { on ro-ro and high-speed } \\
\text { vessels }\end{array}$ & 1999 \\
\hline
\end{tabular}




\section{Situational awareness and officer of the watch}

The job of Officer of the Watch is in itself unique, challenging, dynamic, and above all, responsible. The specifics of the job require quality situational awareness, as there is a constant threat to the ship and crew, from adverse weather conditions to the most mundane activities on deck and in the engine rooms.

Taking into account numerous rules, regulations and adjustments, maritime officers have to perform administrative tasks in addition to regular activities such as navigation. Maintaining the required level of attention and concentration under such conditions for an extended period of time proved to be extremely difficult. After a period of time, factors that significantly reduce situational awareness occur, such as fatigue, stress, and overload (Pico et al. 2015).

An increase in these factors leads to a consistent correlation with a decrease in an individual's cognitive abilities and thus an increased risk for potential accidents. In order to have good situational awareness, watchkeeping officers need to be aware of and pay attention to other vessels in the vicinity, the depth and condition of the sea, and weather conditions. In addition, it is necessary to have knowledge of the vessel's characteristics such as construction, propulsion, equipment and systems. At all times, the position of the ship must be known and the watch officer must allow extra time for unforeseen events and situations ${ }^{6}$.

Situational awareness of ship's officers can be illustrated using Endsley's mental model. The model consists of three levels. Each level must be fulfilled in its entirety to achieve good situational awareness.

Level 1: At this level, the officer of the watch perceives data about the course, speed, and current position of his own ship and other ships in the vicinity (Türkistanli 2019). Perception on the bridge is done using the natural senses of humans such as sight, hearing, smell and touch ${ }^{6}$.

At this stage, the biggest possible mistake would be missing critical information. Since everyone is different, attention and working memory also vary. It is logical that an error at the first stage will affect the other stages as well (Türkistanli 2019).

Level 2: Perceived data must be understood and connected into a meaningful whole. The officer of the watch must understand what the perceived information means to him and his goals, such as navigating a narrow channel, shallow water, or passing through a dangerous crossing (Türkistanli 2019).

Understanding usually consists of a combination of knowledge and experience.

By combining the above, a mental picture of the current situation is formed, such as understanding the voyage plan data, course deviations, and vessel maneuverability. At this level, there is a potential risk of stress, fatigue, work overload and lack of experience, which can affect the understanding of the perceived data and the creation of a mental picture ${ }^{6}$.

Level 3: The third level requires flawless satisfaction of the first two levels. Only then is the officer of the watch able to project a possible outcome in the 
near future. For example, a possible collision or a safe passage (Türkistanli 2019). Figure 2. present three levels of situational awareness.

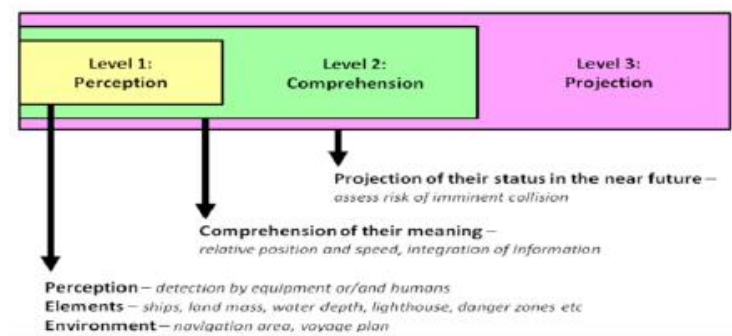

Figure 2. Graphic display of levels of situational awareness in maritime navigation (Wai 2017)

Table 2. Examples of 3 level model: perception, comprehension, projection ${ }^{4)}$

\begin{tabular}{|l|l|l|l|}
\hline Domain & Perception & Comprehension & Projection \\
\hline \multirow{5}{*}{$\begin{array}{l}\text { Hearbour } \\
\text { Location }\end{array}$} & $\begin{array}{l}\text { Sea/Traffic conditions. Port } \\
\text { regulations. Geographical and } \\
\text { tidal conditions. }\end{array}$ & $\begin{array}{l}\text { Projected course of } \\
\text { own vessel and others. } \\
\text { Reporting duties }\end{array}$ \\
\cline { 2 - 4 } & $\begin{array}{l}\text { Traffic on } \\
\text { course }\end{array}$ & $\begin{array}{l}\text { Traffic advisories. Traffic in } \\
\text { the area. IMO regulations to } \\
\text { prevent collisions. Own and } \\
\text { others vessels characteristics }\end{array}$ & $\begin{array}{l}\text { Projected course to } \\
\text { ensure security. Predicted } \\
\text { dangerous manoeuvres. } \\
\text { Radio contact with other } \\
\text { vessels/VTS }\end{array}$ \\
\cline { 2 - 5 } & $\begin{array}{l}\text { Possibility of } \\
\text { failure }\end{array}$ & $\begin{array}{l}\text { Availability of external help } \\
\text { (e.g., tugs, anchorage areas) }\end{array}$ & $\begin{array}{l}\text { Find alternatives to deal } \\
\text { with the failure }\end{array}$ \\
\cline { 2 - 5 } & $\begin{array}{l}\text { Load } \\
\text { status or } \\
\text { passengers }\end{array}$ & $\begin{array}{l}\text { Possibility of cargo damage/ } \\
\text { personal injuries }\end{array}$ & $\begin{array}{l}\text { Efficient navigation, } \\
\text { management of } \\
\text { meteorological } \\
\text { circumstances and } \\
\text { characteristics of the } \\
\text { vessel }\end{array}$ \\
\hline \multirow{4}{*}{$\begin{array}{l}\text { Work } \\
\text { Management } \\
\text { on Board }\end{array}$} & $\begin{array}{l}\text { Resources } \\
\text { available }\end{array}$ & $\begin{array}{l}\text { Type of staff, capacities and } \\
\text { abilities related to work }\end{array}$ & $\begin{array}{l}\text { Work assignment both in } \\
\text { harbour/sailing }\end{array}$ \\
\cline { 2 - 5 } & $\begin{array}{l}\text { Motivation } \\
\text { Bureaucracy }\end{array}$ & $\begin{array}{l}\text { Personal characteristics of the } \\
\text { crew, family, salary, ethnic, etc. }\end{array}$ & Motivational Leadership \\
\cline { 2 - 4 } & Effective time management & $\begin{array}{l}\text { Being able to manage } \\
\text { properly self and } \\
\text { subordinates time } \\
\text { delegating menial jobs }\end{array}$ \\
\hline
\end{tabular}




\section{Maritime accidents causes by poor situational awareness}

Table 3 illustrates the consequences of the deficiency and the importance of maintaining high situational awareness with examples of catastrophic marine casualties.

Table 3. Examples of maritime accidents, caused by human factors that lead to bad situational awareness. Source: Author

\begin{tabular}{|c|c|c|c|c|}
\hline $\begin{array}{l}\text { Name of } \\
\text { the ship }\end{array}$ & Year & Accident & $\begin{array}{l}\text { Cause of the accident - } \\
\text { Human factor / Situational } \\
\text { awareness }\end{array}$ & Consequences \\
\hline \multirow{4}{*}{ RMS Titanic } & \multirow{4}{*}{1912} & \multirow{4}{*}{$\begin{array}{l}\text { Striking } \\
\text { an iceberg } \\
\text { and } \\
\text { sinking }\end{array}$} & Poor lookout & \multirow{4}{*}{1513 deaths } \\
\hline & & & $\begin{array}{l}\text { Sailing full speed in iceberg } \\
\text { infested area }\end{array}$ & \\
\hline & & & $\begin{array}{l}\text { Not using searchlight during } \\
\text { night voyage }\end{array}$ & \\
\hline & & & Poor lifeboat drills & \\
\hline \multirow{2}{*}{$\begin{array}{l}\text { SS Andrea } \\
\text { Doria } \\
\text { and MS } \\
\text { Stockholm }\end{array}$} & \multirow{2}{*}{1956} & \multirow{2}{*}{ Collision } & $\begin{array}{l}\text { Fatal misinterpretation of radar } \\
\text { screens on both ships }\end{array}$ & \multirow{2}{*}{52 deaths } \\
\hline & & & $\begin{array}{l}\text { Andrea Dorias fault in breaking } \\
\text { the rules of the road at sea }\end{array}$ & \\
\hline \multirow{4}{*}{$\begin{array}{l}\text { SS Torrey } \\
\text { Canyon }\end{array}$} & \multirow{4}{*}{1967} & \multirow{4}{*}{ Grounding } & Poor navigation & \multirow{4}{*}{$\begin{array}{l}25-36 \text { million } \\
\text { gallons of crude } \\
\text { oil discharged into } \\
\text { the sea causing } \\
\text { environment } \\
\text { pollution and sea life } \\
\text { destruction }\end{array}$} \\
\hline & & & $\begin{array}{l}\text { Poor communication between } \\
\text { master and helmsman }\end{array}$ & \\
\hline & & & $\begin{array}{l}\text { Orders from master to sail } \\
\text { through the narrow channel to } \\
\text { save time (company pressure) }\end{array}$ & \\
\hline & & & $\begin{array}{l}\text { Failure to notice that ships } \\
\text { steering was on autopilot }\end{array}$ & \\
\hline \multirow{4}{*}{$\begin{array}{l}\text { MS Herald } \\
\text { of Free } \\
\text { Enterprise }\end{array}$} & \multirow{4}{*}{1987} & \multirow{4}{*}{ Capsizing } & Sailing with bow doors open & \multirow{4}{*}{193 deaths } \\
\hline & & & $\begin{array}{l}\text { Fatigue of assistant Bosun } \\
\text { in charge of closing the bow } \\
\text { doors }\end{array}$ & \\
\hline & & & High speed in heavy sea & \\
\hline & & & Company negligence & \\
\hline \multirow{4}{*}{$\begin{array}{l}\text { MV Doña } \\
\text { Paz and MT } \\
\text { Vector }\end{array}$} & \multirow{4}{*}{1987} & \multirow{4}{*}{$\begin{array}{l}\text { Collision } \\
\text { and } \\
\text { sinking }\end{array}$} & $\begin{array}{l}\text { Serious overcrowding on board } \\
\text { Doña Paz }\end{array}$ & \multirow{4}{*}{$\begin{array}{l}\text { Estimated 4000-4500 } \\
\text { deaths }\end{array}$} \\
\hline & & & $\begin{array}{l}\text { Neglect of duty by the crew on } \\
\text { both ships } \\
\end{array}$ & \\
\hline & & & Carelessness & \\
\hline & & & Company negligence & \\
\hline
\end{tabular}


Situational Awareness - Key Safety Factor for the Officer...

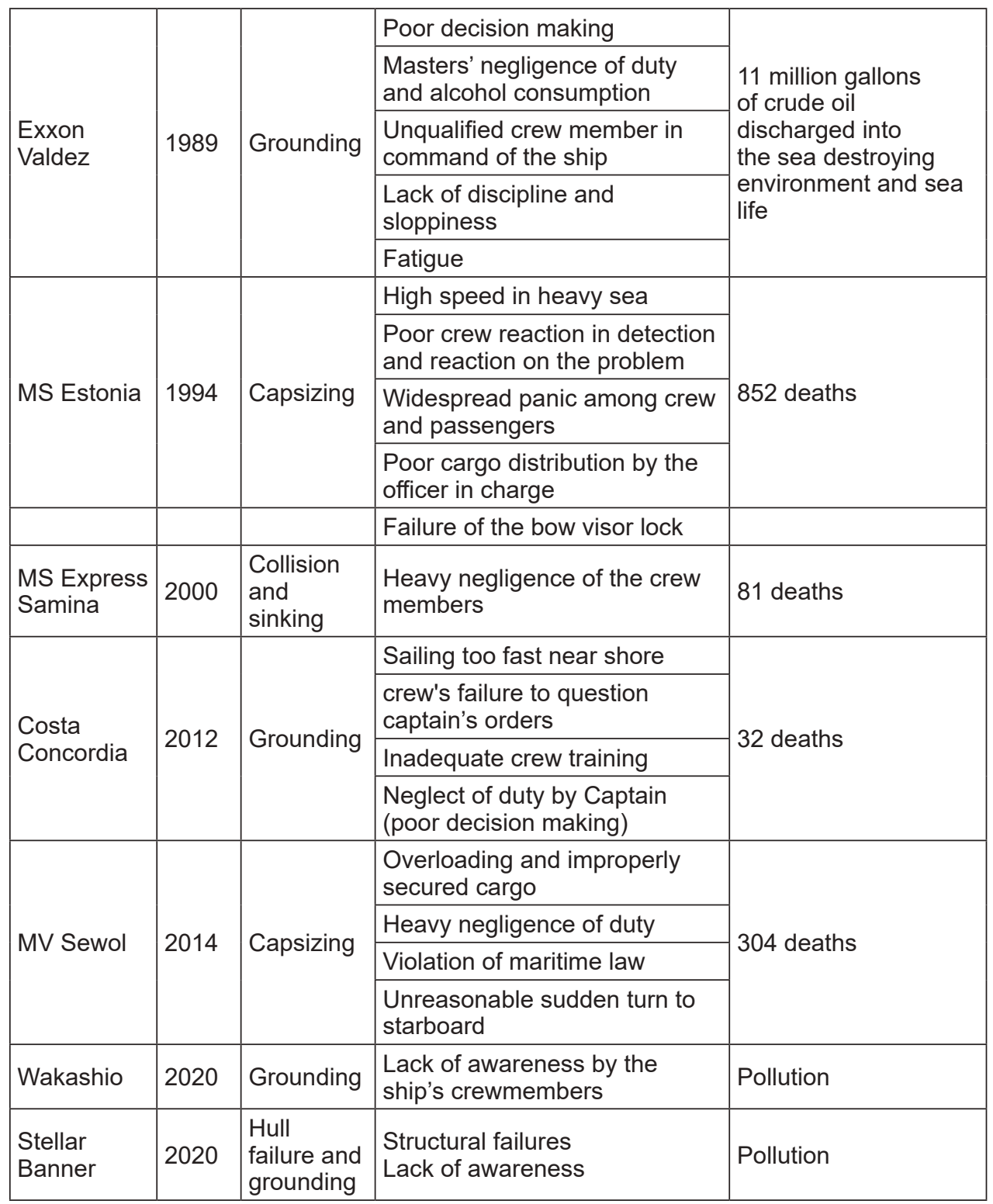

Human behaviour and activities in the casualty column were ultimately caused by or influenced by the development of poor situational awareness, resulting in numerous fatalities and environmental degradation. 


\section{Modern technology as means of help or disruption for the situational awareness}

Technology has had a significant impact on today's maritime industry. To reduce man-made accidents at sea, technological solutions such as integrated navigation systems (AIS, VDR, GPS, RADAR, ECDIS), Central Alert Management Human Machine Interface, CAM-HMI, Integrated Bridge System have been introduced. Naval officers need to frequently monitor and understand the data collected by the devices. Interpretation of the latter is required to understand the current situation in order to make necessary decisions. By reducing the number of crew members on board ships and increasing the number of devices, a counter effect is created in terms of maintaining the necessary situational awareness. First, it is necessary to understand the maritime work environment in order to design the necessary equipment that is suitable for the ship's crew in all situations. If the equipment is poorly designed, e.g. controls and user interfaces are inadequately set, brightness is poor, alarms are too loud or too quiet, all this can seriously reduce crew working efficiency and cause undesirable factors such as stress and fatigue. In addition, technological solutions require a high level of knowledge, skills and training to operate. The Officer of the watch need to know all the benefits and limitations of each device and system, which is very difficult as new technological solutions are introduced relatively quickly in the maritime environment. It is important to mention the issue of overconfidence in the technical means of navigation on the bridge and the low level of habits for visual observation and monitoring, especially when sailing in coastal areas. Simulators represent one of the best technical solutions for increasing situational awareness. They can be used to introduce all future officers of the watch to ship systems, equipment and possible failures and faults of the same. They shorten the time for familiarization and also serve as a support for acquiring the required situational awareness (Pazouki et al. 2018; Bielić et al. 2017).

\section{Survey results and discussion}

The survey was designed and conducted for the target audience of deck/engine maritime officers. The purpose of the survey is to gather relevant data on the importance of situational awareness as a unique skill of an officer of the watch. It also seeks to determine the effectiveness of rules, regulations, and technology in maintaining the required level of situational awareness.

To date, 94 maritime officers have been surveyed, including:

-67 deck officers $(71.3 \%)$,

-27 engineer officers $(28.7 \%)$.

The survey consisted of two parts, first general information about ship officers and second situational awareness questions. The general information related to the age of the ship's officer, experience in sea service, last rank on board, type of ship, and experience with that type of ship. The discussion will focus on how the officers 
answered the questions in the second part on situational awareness in relation to the general information.

A total of 94 officers responded to the survey:

-4 officers $(4.3 \%)$ were between the ages of 20 and 25 ,

-24 officers $(25.5 \%)$ were between 25 and 30 years old,

- 33 officers $(35.1 \%)$ were between 30 and 40 years old,

-23 officers $(24.5 \%)$ were between 40 and 50 years old,

- 10 officers $(10.6 \%)$ were more than 50 years old.

The question on sea service/experience (actual time on board) yielded the following responses $(\mathrm{n}=94)$ :

-7 officers $(7.4 \%)$ had less than 1 year of experience,

-13 officers $(13.8 \%)$ had 1 - 4 years of experience,

-37 officers $(39.4 \%)$ had 4 - 10 years of experience,

- 17 officers $(18.1 \%)$ had 10 - 15 years of experience,

-20 officers $(21.3 \%)$ had more than 15 years of experience.

The question on the last (current) rank on board yielded the following responses $(\mathrm{n}=94)$ :

-25 respondents $(26.6 \%)$ were in rank of 3 Off. / $3 \mathrm{~A} / \mathrm{E}$,

-34 respondents $(36.2 \%)$ were in rank of 2 Off. / $2 \mathrm{~A} / \mathrm{E}$,

-19 respondents $(20.2 \%)$ were in rank of Ch. Off. / 1A/E / ETO,

-16 respondents $(17 \%)$ were in rank of Master / Ch. Eng.

The question on the type of the ship yielded the following responses $(n=94)$ :

- 11 officers $(11.7 \%)$ served on passenger ships,

-44 officers $(46.8 \%)$ served on tankers,

-8 officers $(8.5 \%)$ served on container and Ro-Ro ships,

- 10 officers $(10.6 \%)$ served on offshore vessels,

-13 officers $(13.8 \%)$ served on other type of vessels.

The question on experience on the type of the ship yielded the following responses $(n=94)$ :

- 11 officers had up to 1 year of experience with same type of ship / engine

$(11.7 \%)$,

- 17 officers had 1 to 3 years' experience with same type of ship / engine (18.1\%),

-13 officers had 3 to 5 years' experience with same type of ship / engine $(13.8 \%)$,

- 33 officers had 5 to 10 years' experience with same type of ship / engine $(35.1 \%)$,

-20 officers had more than 10 years' experience with same type of ship / engine

$(21.3 \%)$.

Most of the respondents are deck officers. This is good for the questionnaire because serious accidents (collision, allision, grounding, pollution etc.) happen mainly due to poor awareness of deck officers. If we talk about situational awareness in the engine room, poor awareness can cause damage to equipment 
or injury to individual crew members. Moreover, a sufficient number of respondents are from the engine department, so it is possible to compare the opinion on situational awareness with that of deck officers. 66 officers $(70.2 \%)$ are over 30 years old and 74 officers (78.7\%) have more than 4 years of experience. It can be said that the respondents are mostly experienced seafarers and their opinion on this issue is relevant. The question about the last rank on board shows that there were more junior officers ( $2 \& 3$ Off. and $2 \& 3$ A / E) than senior officers.

Also, 55 officers (58.5\%) sail on high tech ships (tankers and passenger ships) and 53 officers $(56.4 \%)$ have more than 5 years of experience on the same type of ship.

The second part of the survey consists of seven questions related to situational awareness. The questions were asked on a Likert scale from "disagree" to "completely agree". The results are presented with the number and percentage for each scale. The results of this part of the survey are shown in Figure 3.

The questions are:

1. Do you agree that human factor or poor situational awareness is the root cause of accidents at sea?

2. Do you think the concept of situational awareness is taken seriously and recognized in the maritime industry?

3. Modern ship technology and equipment help and improve situational awareness on board. (Ship ergonomics is an important factor in situational awareness).

4. Increasing the number of shipboard equipment, devices, sensors, and alarms and decreasing the number of crew members has the opposite effect of increasing situational awareness.

5. Contract extension has a negative impact on the officer's situational awareness.

6. Do you agree that numerous resolutions, conventions, safety requirements, procedures, and checks have a positive impact on the officer's situational awareness?

7. Stress, fatigue, and anxiety have a negative impact on situational awareness.
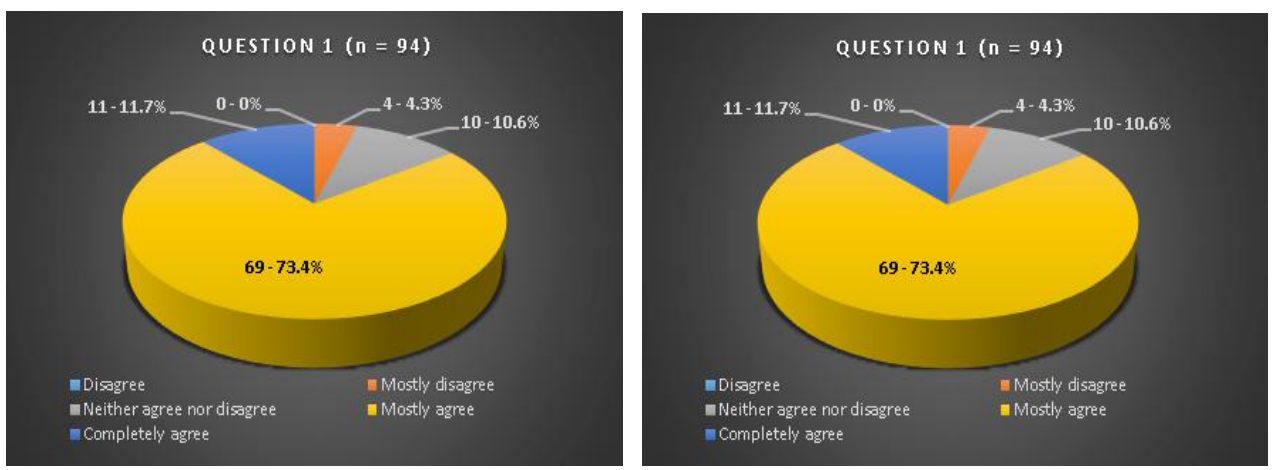

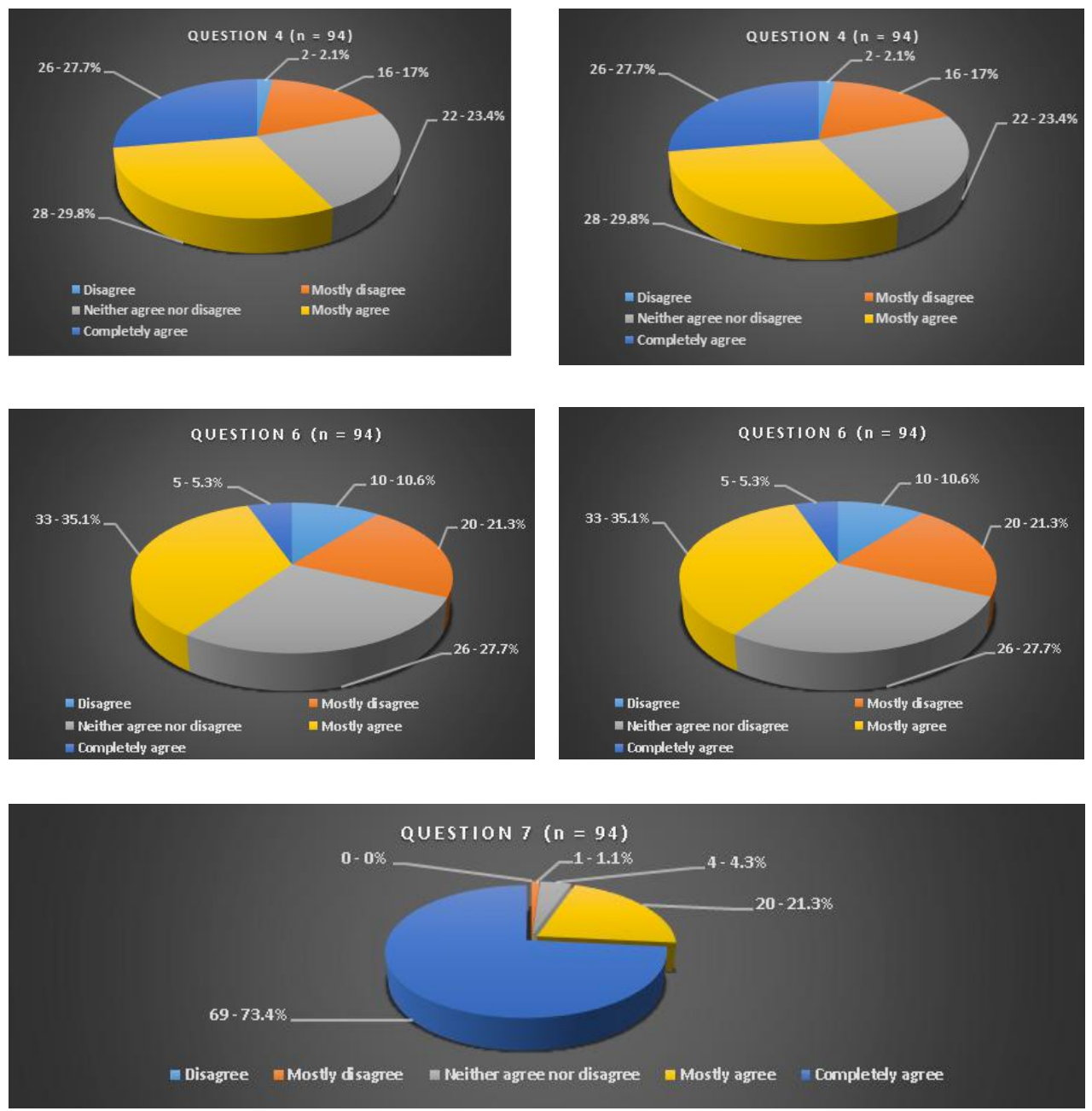

Figure 3. Results for questions $1-7$

Most officers agree that the human element or poor situational awareness is a root cause of maritime accidents, although it is acknowledged and taken seriously by the maritime industry. The problem could lie in the vast amount of procedures, checklists and paperwork that can distract officers, especially when they are in a situation where they have to make important decisions. Of course, procedures are necessary and they are an important safety factor, but with a reduced number of crew members, it is not easy to maintain a high level of situational awareness and follow all the prescribed procedures. For this reason, good planning and preparation 
is essential so that in critical situations the officer can keep in mind the situation and the problem for which the safest and best possible decision must be made. The maritime industry should invest in and promote well-organized and prepared training and education for the specific types of ships. Situational awareness as a human element should be an important part of this process.

67 officers $(71.3 \%)$ agree that ship ergonomics is an important factor in situational awareness. However, the opinions of crew members are divided on question 4 . A closer analysis shows that officers under 30 years of age and with less than 4 years of experience see nothing controversial in question 4 . This is logical as they are used to such a situation on board from the beginning, unlike more experienced officers who sailed at a time when the number of crew members was much larger. The ideal solution would be somewhere in the middle: quality equipment and good ergonomics with a sufficient number of well-trained and educated crew members. On such a ship, it is much easier to maintain a high level of situational awareness.

Of course, when we talk about the length of officer contracts, everyone agrees that the extension has a negative impact on situational awareness. This issue is particularly relevant today, during the Covid -19 pandemic, with some officers staying on board for up to a year. This certainly does not contribute to safety in general. The extension of the contract and the uncertainty with the date of disembarking creates a negative atmosphere on board. A one month or 15 day extension is not a problem and is stated in the contract, but a multi-month extension is never welcome. The same was confirmed in question 7 where 89 officers (94.7\%) agreed that stress, fatigue and anxiety have a negative impact on situational awareness. For question 6 , the opinion of the officers was divided, but it should be noted that a considerable number of them have no opinion or disagree with this statement.

\section{Conclusion}

There is no question that situational awareness is essential and an important safety factor in the maritime world. An Officer of the watch who possesses a high degree of situational awareness can find a solution to a seemingly hopeless situation and save lives. Unfortunately, the importance of situational awareness was only realized after the occurrence of many maritime disasters. In addition, international organisations such as the International Maritime Organisation and the World Health Organisation are trying to improve maritime safety through numerous conventions, rules and regulations, but the increasing commercialization of the maritime industry makes it difficult for them to do so. Commercialization means the maximum exploitation of ships and crew by shipping companies to increase their profits, without regard to the dangers. The so-called commercial pressure is a major problem for the crew on board. It should also be noted that technology has significantly impacted today's maritime industry in terms of supporting safety and 
situational awareness as such on ships. Combining all the data and analyses on the relationship between technology and situational awareness, it is clear that the benefits of technology outweigh the disadvantages of the same. Furthermore, in order to maximize the level of situational awareness on board ships, the cooperation of all parties involved in the maritime enterprise is required. Aside from the role of international organisations and technology, the human factor in maritime accidents will only decrease with the establishment of healthy behavior among future maritime officers.

\section{NOTES}

1. Medical Surge Capacity, 2010. Washington, D.C.: National Academies Press

2. International Maritime Ogranisation, 2021. Available from: https://www.imo. org/en/About/Pages/Default.aspx (accessed Apr. 24, 2021).

3. IMO, International Maritime Organization, International Convention on Standards of Training, Certification and Watchkeeping for Seafarers, 1978. (2019). IMO, 2019. https://www.imo.org/en/OurWork/HumanElement/Pages/ STCW-Convention.aspx (accessed Apr. 25, 2021).

4. International Labour Organization and International Maritime Organization, 2013. Guidelines on the medical examinations of seafarers, 2013. Available from: https://www.ilo.org/wcmsp5/groups/public/---ed_dialogue/---sector/ documents/normativeinstrument/wcms_174794.pdf (accessed Apr. 26, 2021).

5. International Labour Organization and International Maritime. Guidelines on the medical examinationsof seafarers. First publ. 2013

6. Maritime Safety Queensland. Situational awareness. Available from: https:// www.msq.qld.gov.au/Safety/Situational-awareness (accessed Apr. 25, 2021).

\section{REFERENCES}

Barnett, M. L., 2005. Searching for the root causes of maritime casualties: Individual competence or organisational culture? WMU J. Marit. Aff. 4(2), 131-145. doi: 10.1007/BF03195070.

Bielić, T., Hasanspahić, N. \& J. Čulin, 2017. Preventing marine accidents caused by technology-induced human error. Pomorstvo 31(1), 33 - 37. doi: 10.31217/p.31.1.6.

Cordon, J. R., Mestre, J. M.\& J. Walliser, 2017. Human factors in seafaring: The role of situation awareness. Saf. Sci. 93[Mar], 256 - 265. doi: 10.1016/j. ssci.2016.12.018.

Endsley, M. R., 1995. Toward a Theory of Situation Awareness in Dynamic Systems. Hum. Factors J. Hum. Factors Ergon. Soc. 37(1), 32 - 64. doi: 10.1518/001872095779049543. 
Endsley, M. R., 2015. Situation awareness misconceptions and misunderstandings. J. Cogn. Eng. Decis. Mak. 9(1), 4 - 32. doi: $10.1177 / 1555343415572631$.

Koskinen-Kannisto, A., 2013. Situational Awareness Concept in a Multinational Collaboration Environment. National Defense University Helsinki.

Pazouki, K., Forbes, N., Norman, R. A. \& M. D. Woodward, 2018. Investigation on the impact of human-automation interaction in maritime operations. Ocean Eng. 153 [October 2017], 297 - 304. doi: 10.1016/j.oceaneng.2018.01.103.

Pico, M., Hoogervegt, D., Bik, R., Van Der Wiel, S., Batenburg, R. V. B. \& M. Officer, 2015. Enhancing Situational Awareness. [March, 2015].

Schröder-Hinrichs, J.-U., Hollnagel, E., Baldauf, M., Hofmann, S. \& A. Kataria, 2013. Maritime human factors and IMO policy. Marit. Policy Manag. 40(3), 243-260. doi: 10.1080/03088839.2013.782974.

Sandhåland, H., Oltedal, H. \& J. Eid, 2015. Situation awareness in bridge operations - A study of collisions between attendant vessels and offshore facilities in the North Sea. Saf. Sci. 79, 277 - 285 [Nov. 2015]. doi: 10.1016/j. ssci.2015.06.021.

Towns, B. K., 2007. Situational Awareness in the Marine Towing Industry Boris. Türkistanli, B., 2019. Training situational awareness and decision making for preventing collision at sea. Mersin Univ. J. Marit. Fac. 1 [March], 10-16.

Vidan, P., Vukša, S.\& T. Dlabač, 2018. Practice Of And Attitudes Toward Familiarisation On Board: Survey Of Croatian And Montenegrin Maritime Officers. Brodogradnja 69(3), 97-110. doi: 10.21278/brod69306.

Wai, A., 2017. Maritime Collision Detection and Advisory System (MCDAS) Improving Situation Awareness and Enabling Lean Manning. Available from: https://www.semanticscholar.org/paper/Maritime-Collision-Detection-andAdvisory-System-(-Wai/daa6aef86d0508a9c6ed7635734559e0cb3389c4.

$\triangle$ Hrvoje Jaram

Pero Vidan

Web of Science Researcher ID: D-8527-2017

Srđan Vukša

https://orcid.org/0000-0003-3185-3308

Ivan Pavić

Faculty of Maritime Studies

University of Split

Split, Croatia

E-mail:hjaram@pfst.hr

E-mail: pvidan@pfst.hr

E-mail: svuksa@pfst.hr

E-mail: ipavic@pfst.hr 